\title{
Association rule mining untuk menemukan pola hubungan antara kendala menyusun skripsi dan kondisi psikologis mahasiswa
}

\author{
Fana Wiza $^{1}$, Mariza Devega ${ }^{2}$, Susi Handayani ${ }^{3}$ \\ 1,3Program Studi Sistem Informasi Fakultas Ilmu Komputer Universitas Lancang Kuning \\ ${ }^{2}$ Program Studi Teknik Informatika Fakultas Ilmu Komputer Universitas Lancang Kuning \\ Jl. Yos Sudarso KM. 8 Rumbai, Pekanbaru, Riau, telp. 08117532015 \\ e-mail: ${ }^{1}$ fana@unilak.ac.id, ${ }^{2}$ Marizadevega@unilak.ac.id, ${ }^{3}$ susi@unilak.ac.id
}

\begin{abstract}
Abstrak
Sebagian besar mahasiswa cenderung mengalami kendala dalam menyusun skripsi. Hanya sebagian mahasiswa yang berhasil mencapai tahap ujian komprehensif. Kendalanya adalah sulitnya membagi waktu antara skripsi dan aktivitas lain, sulitnya menemui dosen, sulitnya memperoleh sumber referensi, dan kurangnya sarana dan prasarana sehingga mempengaruhi kondisi psikologis mahasiswa. Beberapa mahasiswa mengalami gejala stres. sejak proses bimbingan skripsi dimulai. Penelitian ini bertujuan untuk memperoleh pola dari kendala menyusun skripsi dengan kondisi psikologis mahasiswa menggunakan association rule mining dengan algoritma apriori. Dalam konteks IPTEKS, penelitian ini bertujuan untuk mengembangkan bidang kajian data mining tentang kemampuan algoritma apriori ke arah bidang psikologi. Pola yang dihasilkan akan menggambarkan sebab akibat yaitu kendala utama apa yang dialami mahasiswa skripsi dan gejala stress yang dialami. Hal ini dapat menjadi pertimbangan mahasiswa, dosen pembimbing dan bagian akademik mencari solusi sekesainya skripsi tepat waktu. Proses analisis ini juga membuktikan bahwa association rule mining dengan apriori tidak hanya mampu menangani data belanja tetapi juga mampu menangani data bidang lainnya.
\end{abstract}

Kata kunci : komprehensif, stress, skripsi, apriori, psikologi

\begin{abstract}
Most students tend to experience problems in writing a thesis. Only some students who successfully reach the comprehensive examination stage. The problem is the difficulty of dividing the time between thesis and other activities, the difficulty of meeting lecturers, the difficulty in obtaining reference sources, and the lack of facilities and infrastructure that affect the psychological condition of students. Some students experience stress symptoms. since the thesis guidance process begins. This study aims to obtain a pattern of constraints in composing a thesis with the psychological condition of students using association rule mining with a priori algorithms. In the context of science and technology, this study aims to develop a field of data mining studies about the ability of a priori algorithms towards the field of psychology. The resulting pattern will describe the cause and effect of the main constraints experienced by the thesis student and the symptoms of stress experienced. This can be considered by students, supervisors and the academic section to find solutions to complete their thesis on time. This analysis process also proves that association rule mining with a priori is not only able to handle shopping data but also able to handle other field data.
\end{abstract}

Keywords: comprehensive, stress, thesis, a priori, psychological 


\section{Pendahuluan}

Penyusunan skripsi yang diaplikasikan dalam bentuk karya ilmiah merupakan kendala yang menyebabkan mahasiswa merasa terbebani dalam menyelesaikan pendidikan akademis [8]. Secara umum, dalam penyusunan skripsi ada beberapa prosedur yang harus dilalui oleh mahasiswa yaitu kelengkapan administrasi, seleksi judul, bimbingan dosen, ujian proposal, dan terakhir ujian komprehensif. Sebagian besar mahasiswa cenderung mengalami kendala-kendala dalam menyusun skripsi, karena dari mahasiswa yang mengajukan judul skripsi dan sudah menjalankan proses bimbingan skripsi, tidak seuruhnya yang berhasil mencapai tahap ujian komprehensif. Kendala-kendala tersebut seperti sulitnya membagi waktu antara skripsi dan pekerjaan, sulitnya menemui dosen pembimbing, sulitnya memperoleh referensi, dan kurangnya sarana prasarana. Kendala tersebut menambah tekanan pada mahasiswa. Selain itu, ada juga keluhan lain yaitu tidak adanya solusi yang pasti dari hasil koreksi yang diberikan dosen saat bimbingan. Beberapa mahasiswa bahkan mengalami gejala stres seperti gangguan tidur dan gangguan emosional sejak proses bimbingan skripsi dimulai.

Seseorang dapat dikatakan mengalami stres ketika seseorang tersebut merasa tertekan akibat tuntutan-tuntutan dalam diri dan lingkungan. Stres tidak selalu berdampak negatif (distress) pada individu, ada juga yang berdampak positif (eustress) yang disebabkan oleh adanya perbedaan karakteristik masing-masing individu [8]. Perbedaan karakteristik tersebut akan menentukan respon individu terhadap stimulus yang menjadi sumber stres, sehingga respon setiap individu akan berbeda walaupun stimulus yang menjadi sumber stresnya sama. Dalam konteks penyusunan skripsi, jika mahasiswa tidak mampu berkomunikasi dengan baik secara interpersonal dengan dosen pembimbing, dapat menimbulkan kesalahpahaman sehingga saran dan kritik yang diberikan dosen pembimbing tidak bisa diterima dengan baik, begitu juga sebaliknya. Komunikasi interpersonal memegang peranan penting dalam pembangunan sumber daya manusia. Namun beberapa bentuk komunikasi interpersonal sering disepelekan, contohnya komunikasi interpersonal antara mahasiswa tingkat akhir dengan dosen pembimbingnya dalam proses penyusunan skripsi. Saat mahasiswa telah menempuh semester akhir dan telah menyelesaikan seluruh mata kuliahnya, mahasiswa dituntut atau diwajibkan untuk membuat suatu karya ilmiah, yaitu skripsi.

Penelitian terkait yang pernah dilakukan adalah penelitian yang dilakukan oleh Puput Citra Yulia, dkk pada tahun 2015 [10]. Penelitian ini mengkaji pengaruh komunikasi interpersonal mahasiswa dan dosen pembimbing skripsi terhadap gejala stres mahasiswa dalam menyusun skripsi. Penelitian ini menggunakan tehnik analisis data kuantitatif, karena data yang berwujud angka-angka (kuantitatif). Penelitian ini meneliti ada tidaknya pengaruh komunikasi interpersonal mahasiswa dan dosen pembimbing skripsi dengan gejala stres mahasiswa dalam menyusun skripsi. Dalam penelitian ini terdapat satu variabel independent dan satu variabel dependent. Penelitian menghasilkan kesimpulan bahwa terdapat pengaruh antara komunikasi interpersonal mahasiswa dan dosen pembimbing skripsi terhadap gejala stres mahasiswa, yang ditunjukkan dengan nilai interpretasi koefisien korelasi (r) yaitu 0,665 yang termasuk kategori kuat dalam hal keterbukaan, empati, sikap mendukung, sikap positif dan kesetaraan. Pada observasi yang peneliti lakukan, ditemukan ada faktor lain yang dapat mempengaruhi gejala stres mahasiswa. Adapun faktor lain tersebut adalah status pekerjaan, status pernikahan, masalah keluarga, kesulitan materi dan tidak adanya motivasi dalam diri mahasiswa tersebut untuk mengerjakan skripsi sehingga faktor lain ini juga dapat berpengaruh dan memicu gejala stres mahasiswa. Oleh sebab itu, penting bagi mahasiswa yang sedang menyusun skripsi untuk memperbaiki hubungan komunikasi interpersonal dengan dosen pembimbing agar menimbulkan kenyamanan saat bimbingan skripsi.

Association rule mining merupakan salah satu teknik yang terlibat dalam proses yang disebutkan di atas dan tentang data mining yang paling banyak dipelajari. Hasilnya dapat secara efektif digunakan untuk mengungkap hubungan yang tidak diketahui, menghasilkan hasil yang dapat memberikan dasar untuk peramalan dan pengambilan keputusan. Association Rule dapat 
digunakan untuk menemukan hubungan atau sebab akibat. Masalah asli yang ditangani oleh association rule mining adalah menemukan korelasi antara penjualan produk yang berbeda dari analisis data supermarket. Saat ini, penelitian pada association rule mining dimotivasi oleh berbagai area aplikasi, seperti perbankan, manufaktur, perawatan kesehatan, dan telekomunikasi [7]. Sejumlah algoritma aturan asosiasi telah dikembangkan dalam beberapa tahun terakhir, yang dapat diklasifikasikan ke dalam dua kategori: (a) calon generasi atau uji pendekatan seperti Apriori; (b) pola pendekatan pertumbuhan. Sebuah tonggak dalam studi kategori pertama adalah pengembangan berbasis Apriori [1].

Berdasarkan kondisi di atas maka peneliti bermaksud melakukan pengembangan bidang kajian data mining tentang kemampuan metode association rule mining berbasis algoritma apriori dengan menganalisa pola hubungan kendala menyusun skripsi dengan kondisi psikologis mahasiswa.

\section{Metode Penelitian}

Penelitian dilakukan di lingkungan Fakultas Ilmu Komputer Universitas Lancang Kuning. Sebagai langkah awal maka perlu adanya studi literatur untuk menentukan metode data mining yang manakah untuk mengekstrak data dan algoritma yang tepat dalam penentuan alternatif solusi. Selanjutnya identifikasi masalah berkenaan dengan masalah yang di bahas, kemudian dilakukan pengumpulan data berkaitan dengan permasalahan yang akan dibahas, kemudian dilakukan pengumpulan data untuk menentukan parameter-parameter yang akan dijadikan landasan dalam penelitian.

Pelaksanaan penelitian memerlukan suatu kerangka kerja sebagai panduan. Metode yang digunakan adalah Association Rule dengan algoritma apriori. Langkah-langkah yang dilakukan adalah:

1. Identifikasi Masalah : menggali permasalahan yang ditemukan pada obyek yang diteliti guna mencari alternatif solusi yang terkait dengan permasalahan.

2. Pengumpulan Data : tahap ini penulis mencari bahan-bahan dasar dalam penelitian ini yaitu menyebar angket pada mahasiswa yang telah menyelesaikan skripsi.

3. Pra Proses : tahap praproses ini meliputi pembersihan data (data cleaning), integrasi data (data integration), task relevant data.

4. Data Mining : tahap ini merupakan tahap memproses, yaitu proses association rule mining dengan algoritma apriori.

5. Presentasi pengetahuan (knowledge presentation) merupakan visualisasi dan penyajian pengetahuan yang diperoleh pengguna. Proses ini memformulasikan keputusan atau aksi dari hasil yang didapat. Ada kalanya hal ini harus melibatkan orang-orang yang tidak memahami data mining. Karenanya presentasi hasil data mining dalam bentuk pengetahuan yang bisa dipahami semua orang adalah satu tahapan yang diperlukan dalam proses data mining.

6. Setelah itu dilakukan Pattern Evaluation, mengevaluasi knowledge didapat. Tahap ini merupakan proses pemeriksaan apakah pola yang ditemukan bertentangan denga fakta. Pada proses ini pola yang dihasilkan oleh penulis dibandingkan dengan pola yang dihasilkan melalui software data mining.

\section{Hasil dan Pembahasan \\ 3.1 Pra Proses}

Tahap pra proses ini meliputi pembersihan data (data cleaning), integrasi data (data integration), task relevant data yaitu melakukan seleksi data yang memiliki atribut yang relevan. Dengan melakukan seleksi data akan membantu tahapan proses data mining dalam menemukan pola data yang berguna, yang merupakan proses transformasi. Pada pembersihan data, data-data yang tidak lengkap isinya tidak dilibatkan dalam proses mining. Dan data-data yang lengkap isinya, dipilih beberapa atribut agar data yang akan diolah benar-benar relevan 
dengan kebutuhan. Dengan demikian akan meningkatkan performa dalam proses mining. Task relevant data yaitu melakukan seleksi data yang memiliki atribut yang relevan. Dengan melakukan seleksi data akan membantu tahapan proses data mining dalam menemukan pola data yang berguna. Oleh karena itu, tidak semua atribut akan digunakan, hanya atribut yang dianggap peneliti berguna dan sebarannya tidak terlalu acak.

Tabel 1. Data Awal

\begin{tabular}{|c|c|c|c|c|c|c|c|c|c|c|c|c|c|c|c|c|c|c|c|c|c|c|c|}
\hline $\begin{array}{l}\mathbf{N} \\
\mathbf{0}\end{array}$ & & insa & & & & & & & & & & & & & & & & & & & & & \\
\hline & $\mathrm{A}$ & $\mathrm{A}$ & $\mathrm{A}$ & $\mathrm{A}$ & B & B & $\mathrm{C}$ & $\mathrm{D}$ & $\bar{D}$ & & $\mathrm{D}$ & $\mathrm{D}$ & $\mathrm{D}$ & $\mathrm{D}$ & $\overline{\mathrm{D}}$ & & & & & & & & \\
\hline 1 & 1 & 2 & 3 & 4 & 2 & 3 & 5 & 1 & 2 & & 4 & 5 & 6 & 7 & 8 & & & & & & & & \\
\hline & A & $\mathrm{A}$ & A & B & B & B & B & $\mathrm{C}$ & $\mathrm{C}$ & & $\mathrm{D}$ & $\mathrm{D}$ & $\mathrm{D}$ & $\mathrm{D}$ & $\mathrm{D}$ & & $\mathrm{D}$ & D & & & & & \\
\hline 2 & 1 & 2 & 3 & 2 & 3 & 4 & 5 & 2 & 5 & & 1 & 2 & 3 & 4 & 5 & & 6 & 7 & & & & & \\
\hline & $\mathrm{A}$ & $\mathrm{B}$ & $\mathrm{B}$ & B & $\mathrm{D}$ & $\mathrm{D}$ & $\mathrm{D}$ & $\mathrm{D}$ & $\bar{D}$ & & $\mathrm{D}$ & & & & & & & & & & & & \\
\hline 3 & 3 & 2 & 3 & 4 & 1 & 2 & 4 & 5 & 6 & & 7 & & & & & & & & & & & & \\
\hline & A & $\mathrm{A}$ & B & $\mathrm{C}$ & $\mathrm{D}$ & $\mathrm{D}$ & $\mathrm{D}$ & $\mathrm{D}$ & $\mathrm{D}$ & & $\mathrm{D}$ & & & & & & & & & & & & \\
\hline 4 & 1 & 3 & 1 & 3 & 1 & 2 & 3 & 5 & 6 & & 7 & & & & & & & & & & & & \\
\hline & A & $\mathrm{A}$ & B & B & B & B & $\mathrm{D}$ & $\mathrm{D}$ & & & & & & & & & & & & & & & \\
\hline 5 & 3 & 4 & 2 & 3 & 4 & 5 & 2 & 8 & & & & & & & & & & & & & & & \\
\hline & $\mathrm{A}$ & $\mathrm{A}$ & B & B & $\mathrm{C}$ & $\mathrm{C}$ & $\mathrm{D}$ & $\mathrm{D}$ & $\bar{D}$ & & & & & & & & & & & & & & \\
\hline 6 & 1 & 3 & 2 & 5 & 2 & 5 & 1 & 2 & 4 & & & & & & & & & & & & & & \\
\hline & A & $\mathrm{A}$ & B & $\mathrm{C}$ & $\mathrm{C}$ & D & $\mathrm{D}$ & $\mathrm{D}$ & & & & & & & & & & & & & & & \\
\hline 7 & 1 & 3 & 2 & 2 & 5 & 1 & 2 & 4 & & & & & & & & & & & & & & & \\
\hline & $\mathrm{D}$ & $\mathrm{D}$ & & & & & & & & & & & & & & & & & & & & & \\
\hline 8 & 1 & 3 & & & & & & & & & & & & & & & & & & & & & \\
\hline 9 & $\begin{array}{l}\mathrm{D} \\
6\end{array}$ & & & & & & & & & & & & & & & & & & & & & & \\
\hline 1 & $\mathrm{~A}$ & $\mathrm{~A}$ & A & B & B & B & B & B & B & & $\mathrm{C}$ & $\mathrm{C}$ & $\mathrm{D}$ & $\mathrm{D}$ & D & & $\mathrm{D}$ & $\mathrm{D}$ & & & & & \\
\hline 0 & 1 & 2 & 3 & 5 & 1 & 2 & 3 & 4 & 5 & & 2 & 3 & 2 & 5 & 6 & & 7 & 8 & & & & & \\
\hline 1 & $\mathrm{~A}$ & B & $\mathrm{B}$ & B & $\mathrm{C}$ & $\mathrm{C}$ & $\mathrm{C}$ & $\mathrm{C}$ & $\bar{D}$ & & $\mathrm{D}$ & $\mathrm{D}$ & $\mathrm{D}$ & & & & & & & & & & \\
\hline 1 & 3 & 2 & 3 & 5 & 1 & 2 & 4 & 5 & 4 & & 5 & 6 & 7 & & & & & & & & & & \\
\hline 1 & A & $\mathrm{A}$ & $\mathrm{A}$ & B & B & $\mathrm{D}$ & $\mathrm{D}$ & $\mathrm{D}$ & $\mathrm{D}$ & & $\mathrm{D}$ & & & & & & & & & & & & \\
\hline 2 & 1 & 2 & 3 & 5 & 4 & 1 & 5 & 6 & 7 & & 8 & & & & & & & & & & & & \\
\hline 1 & $\mathrm{~A}$ & $\mathrm{~A}$ & B & B & $\mathrm{C}$ & $\mathrm{C}$ & $\mathrm{C}$ & $\mathrm{C}$ & $\bar{D}$ & & $\mathrm{D}$ & $\mathrm{D}$ & $\mathrm{D}$ & $\bar{D}$ & & & & & & & & & \\
\hline 3 & 2 & 3 & 2 & 3 & 1 & 2 & 3 & 5 & 1 & & 4 & 5 & 6 & 7 & & & & & & & & & \\
\hline 1 & A & $\mathrm{A}$ & $\mathrm{A}$ & D & B & $\mathrm{C}$ & $\mathrm{C}$ & $\mathrm{C}$ & $\mathrm{C}$ & & $\mathrm{C}$ & $\mathrm{D}$ & $\mathrm{D}$ & D & $\mathrm{D}$ & & $\mathrm{D}$ & D & $\mathrm{D}$ & & ) & & \\
\hline 4 & 1 & 2 & 3 & 1 & 5 & 1 & 2 & 3 & 4 & & 5 & 1 & 2 & 3 & 4 & & 5 & 6 & 7 & & & & \\
\hline 1 & $\mathrm{~A}$ & $\mathrm{~A}$ & A & B & $\mathrm{D}$ & $\mathrm{D}$ & $\mathrm{D}$ & & & & & & & & & & & & & & & & \\
\hline 5 & 1 & 2 & 3 & 2 & 2 & 4 & 5 & & & & & & & & & & & & & & & & \\
\hline 1 & $\mathrm{~A}$ & $\mathrm{~A}$ & $\mathrm{~A}$ & B & B & B & $\mathrm{C}$ & $\mathrm{C}$ & $\bar{C}$ & & $\overline{\mathrm{C}}$ & $\mathrm{D}$ & $\mathrm{D}$ & $\mathrm{D}$ & $\overline{\mathrm{D}}$ & & $\mathrm{D}$ & $\mathrm{D}$ & $\mathrm{D}$ & & & & \\
\hline 6 & 2 & 3 & 4 & 3 & 4 & 5 & 1 & 2 & 3 & & 5 & 1 & 2 & 3 & 4 & & 5 & 6 & 7 & & & & \\
\hline 1 & $\mathrm{~A}$ & $\mathrm{C}$ & $\mathrm{C}$ & $\mathrm{C}$ & & & & & & & & & & & & & & & & & & & \\
\hline 7 & 3 & 2 & 4 & 1 & & & & & & & & & & & & & & & & & & & \\
\hline 1 & $\mathrm{~A}$ & B & $\mathrm{B}$ & $\mathrm{C}$ & $\mathrm{C}$ & $\mathrm{C}$ & $\mathrm{D}$ & $\mathrm{D}$ & $\bar{D}$ & & $\mathrm{D}$ & & & & & & & & & & & & \\
\hline 8 & 3 & 3 & 5 & 4 & 3 & 5 & 1 & 2 & 5 & & 7 & & & & & & & & & & & & \\
\hline 1 & $\mathrm{~A}$ & $\mathrm{~B}$ & $\mathrm{~B}$ & $\mathrm{C}$ & $\mathrm{C}$ & $\mathrm{D}$ & $\mathrm{D}$ & $\mathrm{D}$ & $\frac{D}{D}$ & & $\mathrm{D}$ & & & & & & & & & & & & \\
\hline 9 & 4 & 3 & 4 & 3 & 5 & 2 & 3 & 4 & 5 & & 6 & & & & & & & & & & & & \\
\hline 2 & A & $\mathrm{A}$ & B & $\mathrm{D}$ & $\mathrm{D}$ & $\mathrm{D}$ & $\mathrm{D}$ & & & & & & & & & & & & & & & & \\
\hline 0 & 2 & 3 & 3 & 1 & 2 & 5 & 6 & & & & & & & & & & & & & & & & \\
\hline 2 & A & B & $\mathrm{D}$ & D & $\mathrm{D}$ & & & & & & & & & & & & & & & & & & \\
\hline
\end{tabular}




\begin{tabular}{|l|l|l|l|l|l|l|l|l|l|l|l|l|l|l|l|l|l|l|l|l|l|l|}
1 & 3 & 3 & 2 & 4 & 5 & & & & & & & & & & & & & & & & & \\
\hline 2 & $\mathrm{~A}$ & $\mathrm{~A}$ & $\mathrm{~B}$ & $\mathrm{~B}$ & $\mathrm{~B}$ & $\mathrm{~B}$ & $\mathrm{C}$ & $\mathrm{C}$ & $\mathrm{C}$ & $\mathrm{D}$ & $\mathrm{D}$ & $\mathrm{D}$ & $\mathrm{D}$ & & & & & & & & & \\
2 & 3 & 4 & 2 & 3 & 4 & 5 & 2 & 3 & 5 & 2 & 5 & 6 & 7 & & & & & & & & & \\
\hline 2 & $\mathrm{~A}$ & $\mathrm{~A}$ & $\mathrm{~B}$ & $\mathrm{~B}$ & $\mathrm{~B}$ & $\mathrm{C}$ & $\mathrm{C}$ & $\mathrm{C}$ & $\mathrm{D}$ & $\mathrm{D}$ & $\mathrm{D}$ & $\mathrm{D}$ & $\mathrm{D}$ & $\mathrm{D}$ & $\mathrm{D}$ & $\mathrm{D}$ & & & & & & \\
3 & 2 & 3 & 2 & 3 & 5 & 2 & 4 & 5 & 1 & 2 & 3 & 4 & 5 & 6 & 7 & 8 & & & & & & \\
\hline 2 & $\mathrm{~A}$ & $\mathrm{~B}$ & $\mathrm{C}$ & $\mathrm{C}$ & $\mathrm{D}$ & & & & & & & & & & & & & & & & & \\
4 & 3 & 2 & 4 & 5 & 8 & & & & & & & & & & & & & & & & & \\
\hline 2 & $\mathrm{~A}$ & $\mathrm{~A}$ & $\mathrm{~B}$ & $\mathrm{~B}$ & $\mathrm{C}$ & $\mathrm{C}$ & $\mathrm{C}$ & $\mathrm{C}$ & $\mathrm{D}$ & $\mathrm{D}$ & $\mathrm{D}$ & $\mathrm{D}$ & $\mathrm{D}$ & $\mathrm{D}$ & $\mathrm{D}$ & & & & & & & \\
5 & 2 & 3 & 3 & 4 & 2 & 3 & 4 & 5 & 1 & 2 & 3 & 4 & 5 & 6 & 7 & & & & & & & \\
\hline 2 & $\mathrm{~B}$ & $\mathrm{D}$ & & & & & & & & & & & & & & & & & & & & \\
6 & 3 & 7 & & & & & & & & & & & & & & & & & & & & \\
\hline 2 & $\mathrm{~A}$ & $\mathrm{~A}$ & $\mathrm{~B}$ & $\mathrm{~B}$ & $\mathrm{~B}$ & $\mathrm{D}$ & $\mathrm{D}$ & & & & & & & & & & & & & & & \\
7 & 2 & 3 & 3 & 4 & 5 & 2 & 6 & & & & & & & & & & & & & & & \\
\hline 2 & $\mathrm{~A}$ & $\mathrm{~A}$ & $\mathrm{~A}$ & $\mathrm{~A}$ & $\mathrm{~B}$ & $\mathrm{~B}$ & $\mathrm{~B}$ & $\mathrm{~B}$ & $\mathrm{~B}$ & $\mathrm{C}$ & $\mathrm{C}$ & $\mathrm{C}$ & $\mathrm{C}$ & $\mathrm{C}$ & $\mathrm{D}$ & $\mathrm{D}$ & $\mathrm{D}$ & $\mathrm{D}$ & $\mathrm{D}$ & $\mathrm{D}$ & $\mathrm{D}$ & $\mathrm{D}$ \\
8 & 1 & 2 & 3 & 4 & 1 & 2 & 3 & 4 & 5 & 1 & 2 & 3 & 4 & 5 & 1 & 2 & 3 & 4 & 5 & 6 & 7 & 8 \\
\hline 2 & $\mathrm{~A}$ & $\mathrm{~B}$ & $\mathrm{~B}$ & $\mathrm{~B}$ & $\mathrm{~B}$ & $\mathrm{~B}$ & $\mathrm{C}$ & $\mathrm{C}$ & $\mathrm{C}$ & $\mathrm{C}$ & $\mathrm{D}$ & $\mathrm{D}$ & $\mathrm{D}$ & $\mathrm{D}$ & $\mathrm{D}$ & $\mathrm{D}$ & & & & & & \\
9 & 3 & 1 & 2 & 3 & 4 & 5 & 2 & 3 & 4 & 5 & 2 & 3 & 4 & 5 & 6 & 8 & & & & & & \\
\hline 3 & $\mathrm{~A}$ & $\mathrm{~B}$ & $\mathrm{~B}$ & $\mathrm{C}$ & $\mathrm{D}$ & $\mathrm{D}$ & $\mathrm{D}$ & $\mathrm{D}$ & & & & & & & & & & & & & & \\
0 & 1 & 3 & 4 & 2 & 1 & 3 & 4 & 5 & & & & & & & & & & & & & & \\
\hline
\end{tabular}

Kode A, B, dan C adalah kode untuk kendala dalam menyusun skripsi. Sedangkan Kode D adalah untuk kondisi psikologis yang dialami mahasiswa. keterangan lengkapnya sebagai berikut :

No. Nomor urut responden

A1.Tempat tinggal saya sangat bising. Sulit untuk fokus dan berkonsentrasi.

A2. Suhu udara rumah saya sangat panas

A3. Saya meras kebingungan dalam mencari referensi buku untuk skripsi saya

A4. Saya merasa Tidak nyaman dengan ruang dosen saya ketika saya melakukan bimbingan skripsi dikarenakan ruangannya terlalu sempit

B1. Saya merasa putus asa saat saya menyusun skripsi karena Tidak adanya dukungan moral dari orang tua saya

B2. Saya merasa berat badan saya menurun karena pola makan saya Tidak teratur ketika saya menyusun skripsi

B3. Saya merasa emosi saya Tidak stabil karena terlalu memikirkan masalah mengenai skripsi

B4. Saya merasa tuntutan dari orang tua untuk lulus cepat membuat saya depresi

B5. Saya frustasi dengan judul skripsi saya karena keterbatasan kemampuan saya

C1. Saya merasa dosen pembimbing saya memaksakan pendapatnya untuk bahan skripsi saya

C2. Saya merasa kebingungan ketika dosen Tidak memberikan alternatif solusi untuk skripsi saya

C3. Saya merasa kebingungan ketika atas penjelasan yang diberikan oleh dosen pembimbing kepada saya untuk revisi skripsi saya

C4. Saya merasa frustasi ketika teman-teman saya Tidak mendukung skripsi saya

C5. Saya merasa frustasi dengan sikap dosen pembimbing yang Tidak peduli dengan saya

tentang skripsi yang saya kerjakan

D1. Saya sering merasa sakit kepala

D2. Saya sering sulit tidur

D3. Saya terlalu sering berkeringat

D4. Saya merasa urat syaraf saya tegang akhir-akhir ini 
D5. Saya cepat merasa lelah

D6. Saya sering merasa gelisah / cemas

D7. Saya merasa depresi dan putus asa jika memikirkan skripsi

D8. Saya menjadi murah marah dan suka mencari kesalahan orang lain

\subsection{Proses}

Memulai association rule mining dengan algoritma apriori terlebih dahulu adalah menentukan minimum support dan minimum confidence. Penting tidaknya suatu aturan asosiatif dapat diketahui dengan dua parameter, yaitu support dan confidence. Support (nilai penunjang) adalah presentase kombinasi item tersebut, sedangkan confidence (nilai kepastian) adalah kuatnya hubungan antar-item dalam aturan asosiasi. Peneliti menentukan minimum support $60 \%$ dan minimum confidence $80 \%$. Aturan asosiasi dianggap menarik jika mereka memenuhi ambang batas minimum support dan ambang minimum confidence. Ambang batas itu dapat ditetapkan oleh pengguna atau pakar domain [6]. Setelah itu lanjut menemukan semua kombinasi dari item. Kemudian masuk ke titik persoalan association rule yang terdiri dari dua proses :

1. Menemukan frequent itemsets, yaitu itemset yang memiliki support yang lebih besar dari minimum support.

a. Subset dari frequent itemset harus merupakan frequent itemset.

b. Menemukan frequent itemset secara iteratif dari l-item sampai dengan $k$-item.

2. Menggunakan frequent itemset (mulai dari 2-itemset) untuk menghasilkan aturan asosiasi.

\subsection{Menemukan Frequent Itemset}

Metode dasar analisis association rule mining analisa pola frekuensi tinggi. Pertama yang dilakukan adalah mencari kombinasi item yang memenuhi syarat minimum dari nilai support. Association rule mining dengan algoritma apriori dibagi menjadi beberapa tahap yang disebut iterasi. Tiap iterasi menghasilkan pola frekuensi tinggi dengan panjang yang sama dimulai dari yang menghasilkan pola frekuensi tinggi dengan panjang satu. Ditetapkan minimum support $60 \%$, maka kandidat yang tidak memenuhi batas minimum support $60 \%$ tidak digunakan sedangkan yang memenuhi memenuhi batasan minimum support diebut iterasi itemsets yang frequent itemsets. Dari data awal pada Tabel 1 dibentuk kombinasi item atau sering disebut itemsets yang pada proses selanjutnya berfungsi sebagai kandidat itemset (k-itemsets). Pada proses ini association rule mining dengan algoritma apriori mulai digunakan.

Tabel 2. Kandidat Itemset

\begin{tabular}{|c|c|c|c|}
\hline Item & Count & Support & $\begin{array}{c}\text { FREQUENT } \\
\text { ITEMSET }\end{array}$ \\
\hline B1 & 4 & $13 \%$ & TIDAK \\
\hline A4 & 6 & $20 \%$ & TIDAK \\
\hline C1 & 6 & $20 \%$ & TIDAK \\
\hline C4 & 7 & $23 \%$ & TIDAK \\
\hline D8 & 8 & $27 \%$ & TIDAK \\
\hline B2 & 10 & $33 \%$ & TIDAK \\
\hline D3 & 10 & $33 \%$ & TIDAK \\
\hline A1 & 11 & $37 \%$ & TIDAK \\
\hline A2 & 12 & $40 \%$ & TIDAK \\
\hline C3 & 12 & $40 \%$ & TIDAK \\
\hline B4 & 13 & $43 \%$ & TIDAK \\
\hline B5 & 14 & $47 \%$ & TIDAK \\
\hline
\end{tabular}




\begin{tabular}{|c|c|c|c|}
\hline C2 & 14 & $47 \%$ & TIDAK \\
\hline C5 & 14 & $47 \%$ & TIDAK \\
\hline D7 & 15 & $50 \%$ & TIDAK \\
\hline D4 & 16 & $53 \%$ & TIDAK \\
\hline B3 & 18 & $60 \%$ & Ya \\
\hline D1 & 18 & $60 \%$ & Ya \\
\hline D5 & 18 & $60 \%$ & Ya \\
\hline D6 & 18 & $60 \%$ & Ya \\
\hline D2 & 20 & $67 \%$ & Ya \\
\hline
\end{tabular}

Nilai support 1-item pada Tabel 5.7 diperoleh dengan cara :

$$
\text { Support }(C 3)=\frac{\text { Jumlah data yang mengandung } C 3}{\text { Jumlah dataset }}=\frac{12}{30}=40 \%
$$

Kandidat tidak memenuhi batas minimum support $60 \%$ tidak digunakan. Sehingga didapat hasil seperti pada Tabel 2. Berikut penjelasan tahapan pada proses mining:

1. Di iterasi pertama, support dari setiap item dihitung dengan men-scan data. Proses ini menghasilkan kandidat itemset. Setelah support dari setiap item didapat, item yang memiliki support tidak sesuai dengan batas minimum support dipilih sebagai pola frekuensi tinggi dengan panjang 1 atau sering disingkat 1 -itemset. Singkatan $k$-itemset berarti satu set yang terdiri dari $k$-item.

Tabel 3. 1-itemset Frequent Itemset (F1)

\begin{tabular}{|c|c|c|}
\hline $\begin{array}{c}\text { 1- } \\
\text { itemset }\end{array}$ & Count & Support \\
\hline A3 & 25 & $83 \%$ \\
\hline B3 & 18 & $60 \%$ \\
\hline D1 & 18 & $60 \%$ \\
\hline D2 & 20 & $67 \%$ \\
\hline D5 & 18 & $60 \%$ \\
\hline D6 & 18 & $60 \%$ \\
\hline
\end{tabular}

2. Iterasi kedua menghasilkan 2-itemset yang tiap set-nya memiliki dua item. Pertama dibuat kandidat 2-itemset dari kombinasi semua 1-itemset. Lalu untuk tiap kandidat 2-itemset ini dihitung support-nya dengan men-scan database. Support artinya jumlah transaksi dalam database yang mengandung kedua item dalam kandidat 2-itemset. Setelah support dari semua kandidat 2-itemset didapatkan, kandidat 2-itemset yang memenuhi syarat minimum support dapat ditetapkan sebagai 2-itemset yang juga merupakan pola frekuensi tinggi dengan panjang 2 .

Tabel 4. 2-itemsets Frequent Itemset (F2)

\begin{tabular}{|cc|c|c|c|}
\hline \multicolumn{2}{|c|}{ 2-item } & Count & Support & $\begin{array}{c}\text { Frequent } \\
\text { Itemset }\end{array}$ \\
\hline B3 & D1 & 9 & $30 \%$ & Tidak \\
\cline { 3 - 5 } D1 & B3 & 9 & $30 \%$ & Tidak \\
\cline { 3 - 5 } B3 & D4 & 10 & $33 \%$ & Tidak \\
\cline { 3 - 5 } D1 & D4 & 10 & $33 \%$ & Tidak \\
\cline { 3 - 5 } D6 & D4 & 10 & $33 \%$ & Tidak \\
\cline { 3 - 5 } D1 & D6 & 11 & $37 \%$ & Tidak \\
\cline { 3 - 5 } D1 & D7 & 11 & $37 \%$ & Tidak \\
A3 & D1 & 12 & $40 \%$ & Tidak \\
\cline { 3 - 5 } D1 & A3 & 12 & $40 \%$ & Tidak \\
\cline { 3 - 5 } & \multicolumn{3}{|c}{}
\end{tabular}




\begin{tabular}{|c|c|c|c|c|}
\hline D1 & D2 & 12 & $40 \%$ & Tidak \\
\hline D1 & D5 & 12 & $40 \%$ & Tidak \\
\hline D2 & D1 & 12 & $40 \%$ & Tidak \\
\hline D2 & D7 & 12 & $40 \%$ & Tidak \\
\hline D5 & D1 & 12 & $40 \%$ & Tidak \\
\hline D5 & D4 & 12 & $40 \%$ & Tidak \\
\hline D6 & D1 & 12 & $40 \%$ & Tidak \\
\hline B3 & D7 & 13 & $43 \%$ & Tidak \\
\hline D2 & D4 & 14 & $47 \%$ & Tidak \\
\hline D5 & D7 & 14 & $47 \%$ & Tidak \\
\hline B3 & D6 & 15 & $50 \%$ & Tidak \\
\hline D6 & B3 & 15 & $50 \%$ & Tidak \\
\hline D6 & D7 & 15 & $50 \%$ & Tidak \\
\hline A3 & D5 & 16 & $53 \%$ & Tidak \\
\hline A3 & D7 & 16 & $53 \%$ & Tidak \\
\hline B3 & D2 & 16 & $53 \%$ & Tidak \\
\hline D2 & B3 & 16 & $53 \%$ & Tidak \\
\hline D2 & D6 & 16 & $53 \%$ & Tidak \\
\hline D5 & A3 & 16 & $53 \%$ & Tidak \\
\hline D6 & D2 & 16 & $53 \%$ & Tidak \\
\hline A3 & B3 & 17 & $57 \%$ & Tidak \\
\hline A3 & D4 & 17 & $57 \%$ & Tidak \\
\hline B3 & A3 & 17 & $57 \%$ & Tidak \\
\hline B3 & D5 & 17 & $57 \%$ & Tidak \\
\hline D2 & D5 & 17 & $57 \%$ & Tidak \\
\hline D5 & B3 & 17 & $57 \%$ & Tidak \\
\hline D5 & D2 & 17 & $57 \%$ & Tidak \\
\hline D5 & D6 & 17 & $57 \%$ & Tidak \\
\hline D6 & D5 & 17 & $57 \%$ & Tidak \\
\hline A3 & D2 & 19 & $63 \%$ & Ya \\
\hline A3 & D6 & 19 & $63 \%$ & Ya \\
\hline D2 & A3 & 19 & $63 \%$ & Ya \\
\hline D6 & A3 & 19 & $63 \%$ & Ya \\
\hline
\end{tabular}

3. Iterasi ketiga menghasilkan 3-itemset yang tiap set-nya memiliki 3 items. Pertama dibuat kandidat 3-itemset. Lalu untuk tiap kandidat 3-itemset ini dihitung support-nya dengan men-scan database. Pada penelitian ini, seluruh support 3-itemset tidak memenuhi syarat minimum support, sehingga tidak ada itemset yang termasuk kategori frequent itemset.

Tabel 5. 3-itemsets Frequent Itemset (F3)

\begin{tabular}{|ccc|c|c|c|c|}
\hline \multicolumn{3}{|c|}{ 3-item } & Count & Support & Confidence & $\begin{array}{c}\text { Frequent } \\
\text { Itemset }\end{array}$ \\
\hline A3 & D6 & D1 & 9 & $60 \%$ & $36 \%$ & Tidak \\
\cline { 3 - 7 } D6 & A3 & D1 & 9 & $60 \%$ & 0 & Tidak \\
\cline { 3 - 6 } A3 & D6 & B3 & 11 & $67 \%$ & $83 \%$ & Ya \\
D6 & A3 & B3 & 11 & $67 \%$ & $61 \%$ & Tidak \\
\cline { 3 - 7 } A3 & D2 & D1 & 13 & $63 \%$ & $83 \%$ & Ya \\
A3 & D2 & D6 & 13 & $63 \%$ & $52 \%$ & Tidak \\
\cline { 3 - 6 } A3 & D6 & D5 & 13 & $63 \%$ & $52 \%$ & Tidak \\
\hline
\end{tabular}




\begin{tabular}{|lll|l|l|l|l|} 
D2 & A3 & D1 & 13 & $63 \%$ & $65 \%$ & Tidak \\
\cline { 3 - 7 } D2 & A3 & D6 & 13 & $63 \%$ & $65 \%$ & Tidak \\
\cline { 3 - 7 } D6 & A3 & D2 & 13 & $63 \%$ & $72 \%$ & Tidak \\
\cline { 3 - 7 } D6 & A3 & D5 & 13 & $63 \%$ & $72 \%$ & Tidak \\
A3 & D2 & B3 & 14 & $67 \%$ & $56 \%$ & Tidak \\
D2 & A3 & B3 & 14 & $67 \%$ & $70 \%$ & Tidak \\
A3 & D2 & D5 & 16 & $63 \%$ & $64 \%$ & Tidak \\
D2 & A3 & D5 & 16 & $63 \%$ & $80 \%$ & Ya \\
\hline
\end{tabular}

\subsection{Pembentukan Aturan Asosiasi}

Tahap kedua adalah pembentukan aturan asosiasi. Kombinasi itemset pada $F 1$, dan $F 2$ untuk selanjutnya disebut rule. Dari rule tersebut, dicari rule yang merupakan association rule atau merupakan aturan asosiatif karena memenuhi syarat minimum confidence, dimulai dari kombinasi 2-itemset. Untuk menghitung confidence digunakan rumus berikut :

$$
\text { Confidence }=\frac{\text { Support }(A \cup B)}{\operatorname{Support} A}
$$

Dari $F 3$ yang telah ditemukan, dapat dilihat besarnya nilai confidence dari 3-itemset seperti tampak pada tabel 6. Dari tabel calon aturan asosiasi $F 3$ diatas telah dihasilkan 3 rule yang mana nilai confidence-nya memenuhi syarat minimum confidence.

Tabel 6. Rules

\begin{tabular}{|c|c|c|c|}
\hline No & Rule & Support & Confid. \\
\hline 1 & Jika A6 dan D6 maka B3 & $83 \%$ & $83 \%$ \\
\hline 2 & Jika A3 dan D2 maka D1 & $83 \%$ & $83 \%$ \\
\hline 3 & Jika D2 dan A3 maka D6 & $80 \%$ & $80 \%$ \\
\hline
\end{tabular}

\subsection{Presentasi Pengetahuan (Knowledge Presentation)}

Hasil dari proses mining menggunakan teknik aturan asosiasi dengan algoritma apriori dapat dilihat pada Tabel 6 dengan atribut itemset, jumlah itemset atau count, support, dan confidence dari itemset tersebut. Dari tabel tersebut dapat dilihat bahwa proses mining untuk menemukan pola hubungan kendala menyusun skripsi dan kondisi psikologis yang dialami mahasiswa dengan minimum support 60\% dan minimum confidence 80\% menghasilkan 3 aturan.

\subsection{Pattern Evaluation}

Adapun tahap pattern evaluation menggunakan Tanagra adalah :

1. Import dataset yang akan digunakan.

2. Pilih pendeskripsi.

3. Penerapan Association Rule dengan algoritma Apriori. Penetapan parameter minimum support dan minimum confidence.

4. Eksekusi algoritma dan menampilkan hasil berupa rules.

Untuk pengujian data dengan sistem komputerisasi harus mempunyai tiga komponen utama, yaitu perangkat keras, perangkat lunak, dan brainware. Pengujian dalam penelitian ini menggunakan perangkat lunak khusus untuk data mining. Setelah dua kali proses mining yang dijalankan, yaitu pada perhitungan manual menggunakan Ms. Excel dan pada pengujian dengan memanfaatkan software data mining, rules atau knowledge yang dihasilkan adalah sama. 


\subsection{Pengujian Menggunakan Tanagra}

Pada tahap ini akan dijabarkan penemuan aturan asosiasi dengan algoritma apriori. Kita harus mengikuti langkah-langkah berikut jika kita ingin menemukan aturan asosiasi dengan algoritma apriori dari sebuah dataset.

1. Import dataset yang akan digunakan. Pertama, kita harus membuat sebuah new diagram dan import dataset dengan menu FILE/NEW. Kemudian pilih file dataset yang telah kita buat sebelumnya. Tanagra mendukung tiga format file, yaitu Text File, WEKA Dataset, dan Excel File (97 \& 2000). Peneliti menggunakan dataset dengan format Excel File (97 $\& 2000)$.

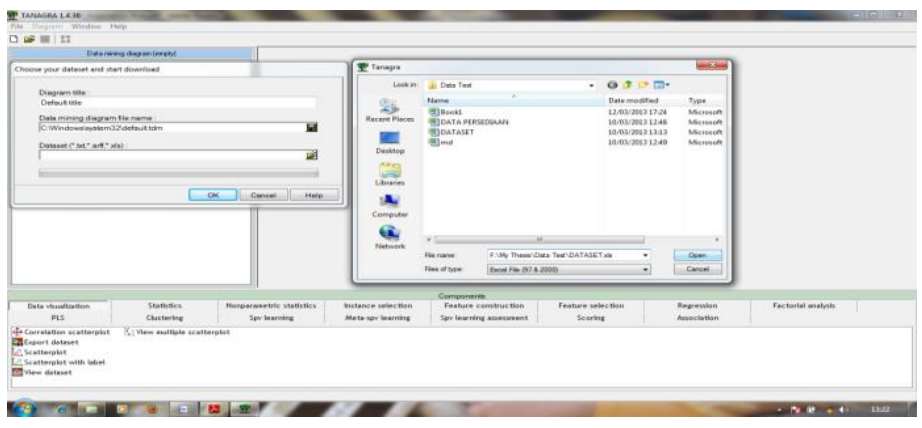

Gambar 1. Langkah Pertama

2. Pilih pendeskripsi. Pada langkah ini yang dilakukan adalah menemukan atribut-atribut untuk dianalisis. Menambahkan komponen Define Status ke dalam diagram, atur semua atribut sebagai input.

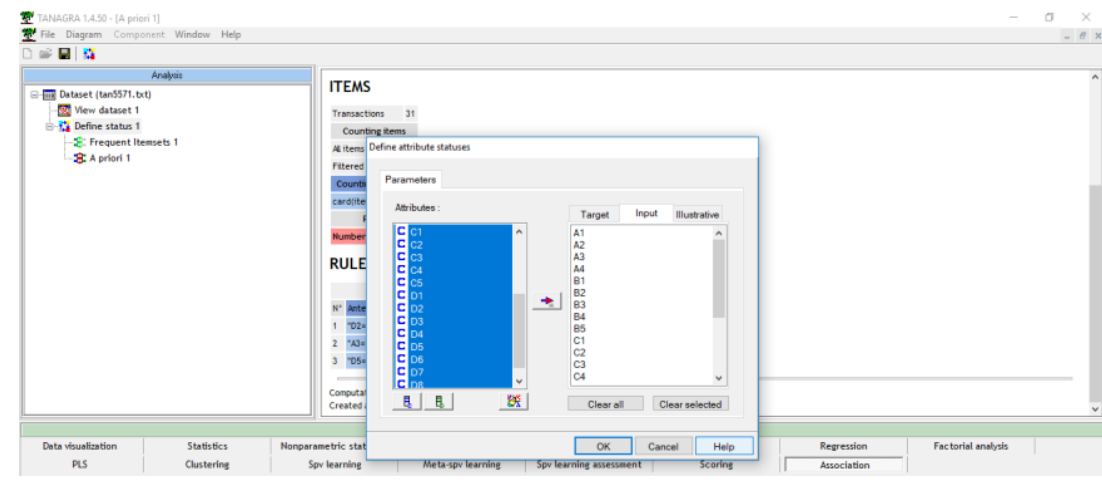

Gambar 2. Langkah Kedua

3. Ada banyak variasi algoritma di dalam Tanagra. Kita akan melakukan association rule mining pada kasus ini dengan menggunakan algoritma Apriori.

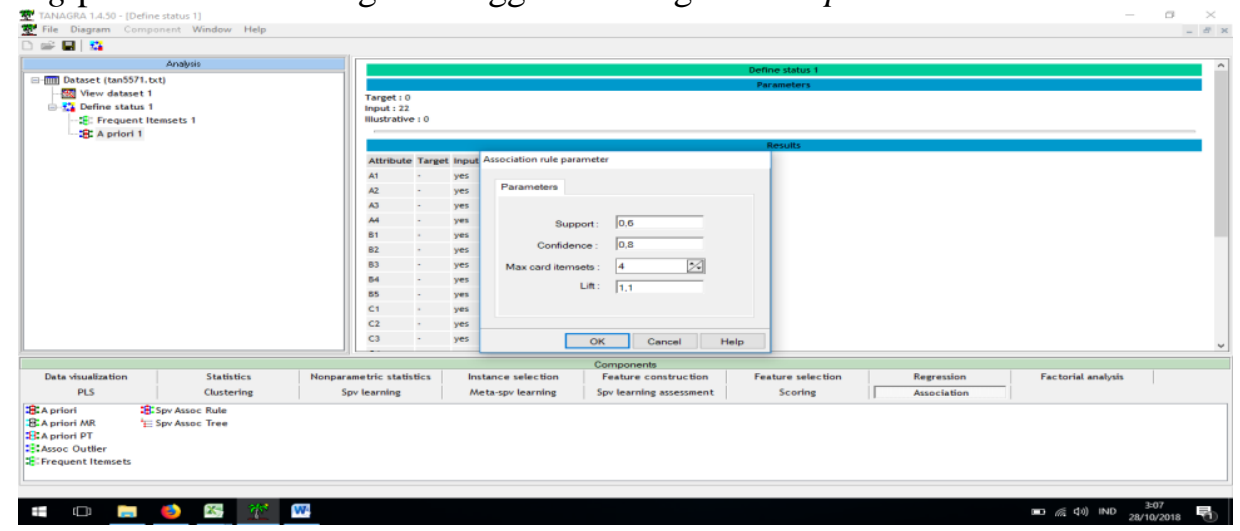

Gambar 3. Langkah Ketiga 
4. Tentukan parameter dari algoritma apriori untuk aturan asosiasi yaitu batas minimum support dan batas minimum confidence. Klik kanan pada komponen A Priori untuk menampilkan menu Parameters. Batas minimum support diatur menjadi 0,6; dan batas minimum confidence diatur menjadi 0.8 , yang kita gunakan sebagai rules adalah hanya yang termasuk frequent itemsets.

5. Eksekusi algoritma dan tampilan rules. Klik kanan pada komponen apriori, pilih Execute. Kemudian kita pilih View untuk melihat rules yang dihasilkan. Rules yang dihasilkan berjumlah 3 .

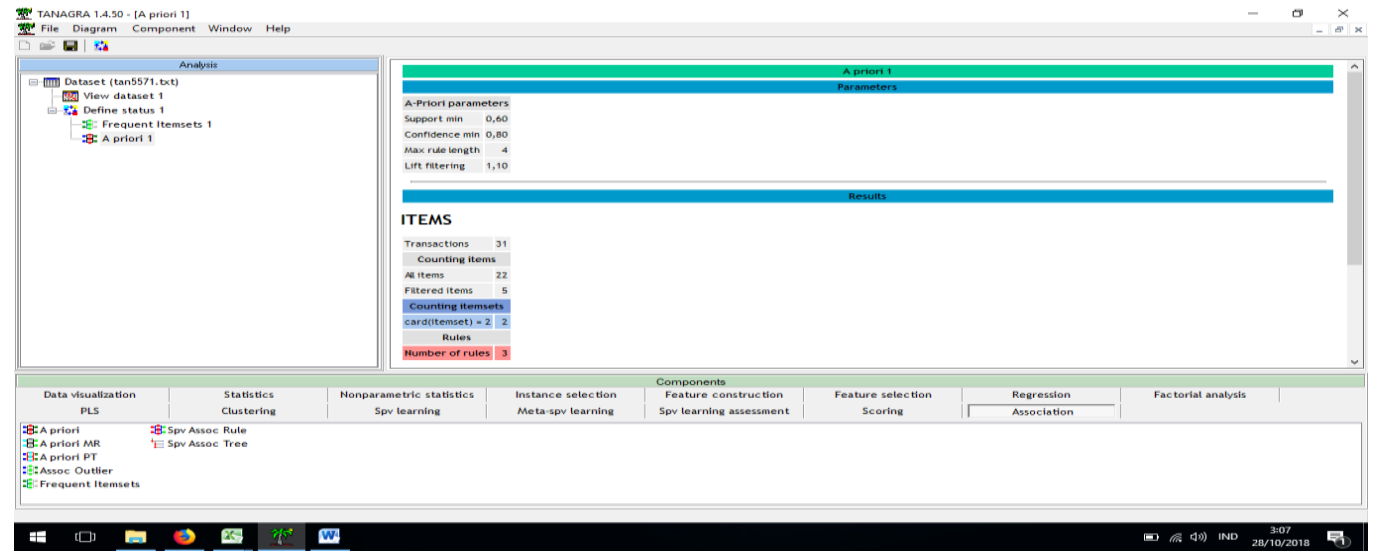

\section{Gambar 4. Rules}

\subsection{Hasil Pattern Evaluation}

Dari pengujian atau pattern evaluation yang telah dilakukan menggunakan software data mining Tanagra. Setelah dua kali proses mining yang dijalankan, yaitu pada perhitungan manual menggunakan Ms. Excel dan pada pengujian dengan memanfaatkan software data mining, rules yang dihasilkan adalah sama. Ini adalah screenshoot hasil pengolahan menggunakan Tanagra.

\section{RULES}

\begin{tabular}{|c|c|c|c|c|c|}
\hline \multicolumn{6}{|c|}{ Number of rules : 3} \\
\hline No & Antecedent & Consequent & Lift & Support (\%) & Confidence (\%) \\
\hline 1 & "A6=true" - "D6=true" & "B3=true" & 1,18095 & 82,516 & 82,832 \\
\hline 2 & "A3=true" - "D2=true" & "D1=true" & 1,18095 & 82,516 & 83,000 \\
\hline 3 & "D2=true" - A3=true" & "D6=true" & 1,12119 & 79,920 & 80,406 \\
\hline
\end{tabular}

Computation time : $32 \mathrm{~ms}$.

Gambar 5. Rules Hasil Tanagra

Pada perhitungan manual dengan bantuan program aplikasi Ms. Excel. Rules yang dihasilkan juga sama. Namun, pada nilai Support dan Confidence menunjukkan angka yang sedikit berbeda namun indikasinya relatif sama.

Tabel 7. Rules Pengolahan Manual

\begin{tabular}{|c|c|c|c|}
\hline No & Rule & Support & Confid. \\
\hline 1 & Jika A6 dan D6 maka B3 & $83 \%$ & $83 \%$ \\
\hline 2 & Jika A3 dan D2 maka D1 & $83 \%$ & $83 \%$ \\
\hline 3 & Jika D2 dan A3 maka D6 & $80 \%$ & $80 \%$ \\
\hline
\end{tabular}




\section{Kesimpulan}

Melalui penelitian ini disimpulkan bahwa :

1. Pola kendala dan kondisi psikologis yang dialami mahasiswa dalam menyusun skripsi di ketiga pola/knowledge yang dihasilkan sama. Yaitu kendala utama yang ditemukan berdasarkan pola adalah mahasiswa kebingungan mencari referensi buku untuk menyusun skripsi yang akhirnya menimbulkan kondisi psikologis merasa emosi yang tidak stabil. Kemudian mengakibatkan kondisi psikologis sering merasa gelisah, cemas, sulit tidur, dan cepat merasa lelah. Dari analisa juga disimpulkan berdampak pada lama penyelesaian skripsi menjadi 6 hingga 12 bulan, atau lebih dari satu semester.

2. Penelitian ini membuktikan bahwa peneliti berhasil mengembangkan bidang kajian data mining tentang kemampuan metode association rule dengan algoritma apriori ke bidang psikologi.

Berbagai upaya dilakukan untuk dapat meningkatkan tingkat akurasi sebuah model khususnya pada data mining. Untuk meningkatkan tingkat akurasi pada hasil analisis penelitian ini, peneliti menyarankan menggunakan model algoritma Support Vector Machine (SVM) atau metode statistik.

\section{Daftar Pustaka}

[1] AL-ZAWAIDAH, Farah Hanna; JBARA, Yosef Hasan; MARWAN, A. L. An Improved Algorithm For Mining Association Rules In Large Databases. World Of Computer Science And Information Technology Journal, 2011, 1.7: 311-316.

[2] AINI, Aliya Noor; MAHARDAYANI, Iranita Hervi. Hubungan Antara Kontrol Diri Dengan Prokrastinasi Dalam Menyelesaikan Skripsi Pada Mahasiswa Universitas Muria Kudus. Jurnal Psikologi: PITUTUR, 2011, 1.2: 65-71.

[3] ARINCY, NUKE; SITANGGANG, Imas Sukaesih. Association Rules Mining Untuk Data Kebakaran Hutan Menggunakan Algoritme ECLAT Dan SPADE. Makalah Kolokium Ekstensi, 2014, 1.1..

[4] BADRUL, Mohammad. Algoritma Asosiasi Dengan Algoritma Apriori Untuk Analisa Data Penjualan. Jurnal Pilar Nusa Mandiri, 2016, 12.2: 121-129.

[5] GUPTA, Vishal, Et Al. A Survey Of Text Mining Techniques And Applications. Journal Of Emerging Technologies In Web Intelligence, 2009, 1.1: 60-76.

[6] HAN, Jiawei; PEI, Jian; KAMBER, Micheline. Data Mining: Concepts And Techniques. Elsevier, 2011.

[7] LAKSHMI, NV Muthu; RANI, Dr K. Sandhya. Privacy Preserving Association Rule Mining Without Trusted Party For Horizontally Partitioned Databases. International Journal Of Data Mining AND Knowledge Management Process (IJDKP) Vol, 2012, 2.

[8] SUBAGIO, Theresia Monica; WARDANI, NATALIA DEWI; HADIATI, Titis. PERBEDAAN PROKRASTINASI AKADEMIK ANTARA MAHASISWA YANG MENGGUNAKAN KOPING STRES BERORIENTASI MASALAH DENGAN KOPING STRES BERORIENTASI EMOSI. 2018. Phd Thesis. Faculty Of Medicine.

[9] Wiza, Fana. "Pemodelan Pola Hubungan Kemampuan Lulusan Universitas Lancang Kuning Dengan Kebutuhan Dunia USAha Dan Industri." Digital Zone: Jurnal Teknologi Informasi dan Komunikasi 7.1 (2016): 11-17.

[10] YULIA, Puput Citra; AFRIANTI, Henny; OCTAVIANI, Vethy. Pengaruh Komunikasi Interpersonal Mahasiswa Dan Dosen Pembimbing Skripsi Terhadap Gejala Stres Mahasiswa Dalam Menyusun Skripsi. JURNAL PROFESSIONAL, 2015, 2.1.; 61-69.

[11] UTARI, Pria Nita; HAKIM, R. B. Penerapan Metode Association Rule Menggunakan Algoritma Apriori Untuk Analisa Pola Data Kecelakaan Pesawat Dari Tahun 1967-2014 Di Indonesia. 2015. 